\title{
Polymyositis Presenting with Distal and Asymmetrical Weakness
}

\author{
MECHERI B. SUNDARAM and EDWARD M. ASHENHURST
}

SUMMARY: A 52 year old female with polymyositis presenting with distal and asymmetrical weakness is presented. Similar reported cases are reviewed. These patients respond favorably to steroids. Increased awareness of this unusual distal polymyositis should avoid delay in diagnosis.

RESUME: Nous discutons l'histoire d'une femme de 52 ans dont la polymyosite sest présentée avec une faiblesse distale et asymétrique. Nous faisons une revue des cas semblables publiés. Ces patients ont répondu favorablement à l'emploi des stéroides. La connaissance accrue de celte polymyosite distale inhabituelle devrait éviter les retards dans le diagnositic.
From the Department of Clinical Neurological Sciences, University Hospital, Saskatoon, Saskatchewan.

Reprint requests to: Dr. E.M. Ashenhurst Department of Clinical Neurological Sciences, University Hospital. Saskatoon. Saskatchewan, Canada S7N 0X0.

\section{INTRODUCTION}

Polymyositis presenting with predominantly distal and asymmetrical weakness is rare. Only five patients have been described in detail. We describe a patient who presented with distal weakness and wasting of the left leg. The literature on this unusual form of polymyositis is reviewed.

\section{CASE HISTORY}

Mrs. M.L. aged 52 presented in 1973 with a two year history of weakness of her left foot. She noted difficulty standing on the toes of the left foot. She also found that her left leg was getting thinner. The symptoms had been slowly progressive. There was no muscle pain, backache or dysphagia. Examination showed moderate wasting of the left calf muscles, associated with moderate weakness of plantar flexion of the left foot. There was minimal weakness of the hamstring muscles on the left. Other muscles were normal. The left ankle jerk was absent. There was no sensory loss. Lumbar spine $x$ rays and nerve conduction velocities of the peroneal nerves were normal. No specific diagnosis was made.

The patient noted increasing weakness of her legs. She had difficulty walking on rough ground and negotiating stairs in 1975-76. During her second hospital admission in 1978, the patient also complained of difficulty standing on the toes on the right side. There were no upper limb symptoms. Her general health remained good without any weight loss. Examination showed wasting of both calf muscles, the left more than the right. There was severe weakness of ankle plantar flexion, greater on the left. Eversion of both feet was weak. Knee flexion and extension on both sides were weak. The knee and ankle jerks were unobtainable. There was no sensory loss or muscle tenderness.
Investigations showed normal hemoglobin and white cell count; ESR in the first hour was $20 \mathrm{~mm}$., platelet count was $157,000 / \mathrm{cu}$. mm. Electrolytes were normal. Serum proteins, calcium, phosphate, and uric acid were normal. Plasma electrophoresis was normal. Serum creatine phosphokinase was $558 \mathrm{lU} / \mathrm{L}$ (normal $0-125$ ) and lactic dehydrogenase $285 \mathrm{IU} / \mathrm{L}$ (normal 100270). SGOT was $33 \mathrm{IU} / \mathrm{L}$ (normal 1040). Chest $x$-ray and electrocardiogram were normal. Electromyography using a concentric needle showed occasional fibrillation potentials and positive waves in the left peroneus longus muscle. The left anterior tibial muscle showed some fibrillation potentials and on voluntary contraction, slight reduction in the number of motor units. EMG of the left quadriceps, left gastrocnemius and right anterior tibial muscles showed slight reduction in the number of motor units on maximal muscle contraction. Motor conduction velocities in both peroneal nerves, left median nerve and left ulnar nerve were in the normal range. No definite conclusion was made from these results.

Open biopsy of the right quadriceps muscle showed scattered collections of lymphocytes, macrophages and occasional granular leukocytes in the interstices of the muscle. Remnants of the disintegrating muscle fibers were invaded from the periphery by the inflammatory cells (Fig. 1). Electron microscopic examination of the muscles not involved in the inflammatory process showed normal architecture. Inclusion bodies were not seen.

The patient was treated initially with glucocorticoid for about four months. Serum CPK fell to $353 \mathrm{IU} / \mathrm{L}$; LDH was 254 (normal 100-290). It had to be discontinued because of epigastric pain and water retention. Subsequently azathioprine was started at a dose of 


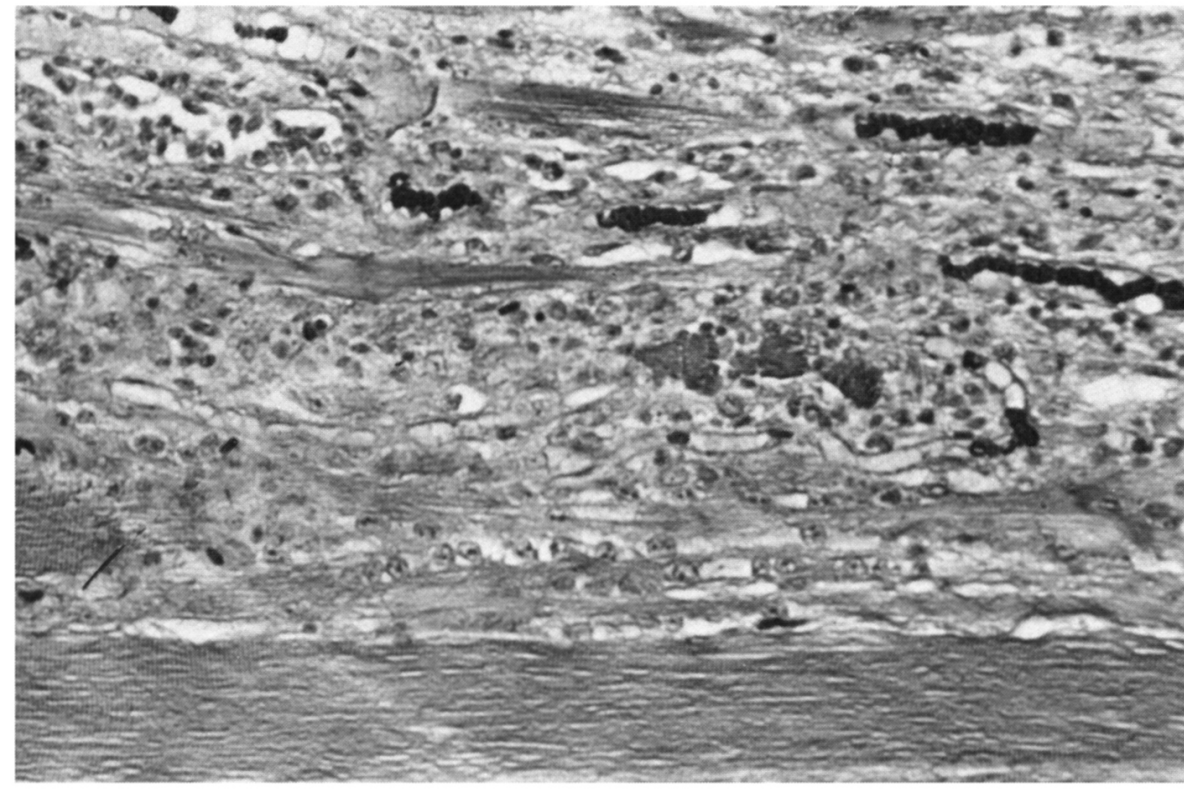

Figure I - Histology of muscle biopsy from the right quadriceps, showing disintegrating muscle fibers and interstitial lymphocytes and macrophages. (H\&E mag. x 200).

150 mgms. per day. On this, the patient's symptoms ceased to progress. CPK in January 1980 was $350 \mathrm{IU} / \mathrm{L}$. $\mathrm{LDH}$ and SGOT were in the normal range.

\section{DISCUSSION}

Polymyositis is an inflammatory disease of muscle, usually affecting patients aged 40 to 70 . However, patients in their eighties and children with the disease have been described. It is twice as common in females. Most large series describe patients presenting with symmetrical proximal weakness of limbs (Barwick, et al, 1963; Eaton, 1954; Pearson, 1966; Walton, 1969). The lower limbs are usually affected before the upper limbs. Dysphagia is seen in about $54 \%$ of patients. Skin lesions and Raynaud's phenomenon are also seen. In $15 \%$ of patients internal malignancy is seen (Pearson, 1966). Underlying collagen vascular disorders are seen in 25\% of all patients (Barwick, et al, 1963). Steroids produce complete improvement of weakness in about $50 \%$ of patients and partial arrest in $25 \%$. Considerable difficulty remains in $10 \%$. The overall mortality is about $15-30 \%$ (Pearson, 1966; Rose and Walton, 1966).

The distal muscles are involved in about one-third of all patients. How- ever, this is usually mild and follows the proximal weakness. More severe distal muscle involvement is a late feature in patients with generalized disease (Barwick et al, 1963; Eaton, 1954; Pearson, 1966; Walton, 1969). Polymyositis with onset of asymmetric weakness in the distal muscles is rare. Rose and Walton (1966) mentioned that "weakness beginning in only one extremity was encountered in some cases" among their 89 patients. No further detail was given. Rowland (1977) described one patient with predominantly distal polymyositis but gave no details. Detailed reports are available in only five patients (Eaton, 1954; Hollinrake, 1969; Bates et al, 1973; Stark, 1978; Van Kasteran, 1979): These are summarized in Figure 2. All of these patients were females aged between 45 and 65 . In 3 patients, hand muscles were involved first. In 2 of these the onset was unilateral. In 3 patients, distal leg muscles were affected first. In 2 of these the weakness was asymmetrical. These patients did not have muscle pain. Dysphagia was present in 3 patients. The disease typically ran a slowly progressive course. Eventually, the more proximal muscles were involved.

Although some deep tendon reflexes were absent in our patient and in the patient described by Stark (1978), high
CPK, normal nerve conduction studies and lack of neurogenic changes in the muscle on histology would rule out any primary neurogenic disorder. Subsequent clinical course confirmed that the disorder was not neurogenic.

Recently a group of patients with inflammatory myositis with distal weakness was described by Carpenter, et al, (1978). This was named "Inclusion Body Myositis". These patients were men; the distal muscles were predominantly involved. The course of the disease was slow. The muscle histology showed massive collections of cytomembranous whorls and abnormal cytoplasmic nuclear filaments. There was no resonse to steroids.

We believe that the patients listed in Figure 2 did not have inclusion body myositis for various reasons. They were all female; inclusions were not seen in the muscle cells although electron microspcopy was not done in all the patients. Moreover, they responded favorably to steroids.

There is a small distinct group of patients with polymyositis, where distal, and frequently asymmetrical muscle weakness is the presenting feature. The correct diagnosis is usually not made at an early stage in these patients. Their disease runs a slow course over several years yet responds well to corticosteroids. The factors determining this distribution of muscle involvement are presently unknown.

\section{ACKNOWLEDGEMENT}

We are grateful to Dr. B. Rozdilsky, Neuropathologist, for his help in the interpretation of muscle histology.

\section{REFERENCES}

BARWICK, D.D., WALTON, J.N. (1963). Polymyositis. American Journal of Medicine. 35: 646-660.

BATES, D., STEVENS, J.C., HUDGSON, P. (1973). Polymyositis With Involvement of Facial and Distal Musculature. Journal of Neurological Sciences. 19: 105-108.

CARPENTER, S., KARPATI, G, HELSLER, H., EISEN, A. (1978). Inclusion body myositis: A distinct variety of idiopathic inflammatory myopathy. Neurology 28: 817. 
FIGURE II

Details of Patients With Polymyositis Presenting With Predominant Distal Weakness

\begin{tabular}{|c|c|c|c|c|c|c|c|c|c|}
\hline Author & $\begin{array}{l}\text { Pi.'s } \\
\text { age } \\
\text { in } \\
\text { yrs. }\end{array}$ & Sex & $\begin{array}{l}\text { Predominant muscles } \\
\text { involved }\end{array}$ & $\begin{array}{c}\text { Duration of } \\
\text { weakness when } \\
\text { diagnosed in } \\
\text { years }\end{array}$ & $\begin{array}{c}\text { Dys- } \\
\text { phagia }\end{array}$ & $\begin{array}{l}\text { Muscle } \\
\text { Pain }\end{array}$ & CPK & Biopsy & $\begin{array}{c}\text { Response to } \\
\text { steroids }\end{array}$ \\
\hline Eaton 1954 & 48 & $\mathrm{~F}$ & $\begin{array}{l}\text { Below the knee. Upper } \\
\text { facial muscles }\end{array}$ & 3 & yes & $\begin{array}{c}\text { not } \\
\text { known }\end{array}$ & $\begin{array}{c}\text { not } \\
\text { known }\end{array}$ & positive & not known \\
\hline Hallinrake 1969 & 65 & $\mathrm{~F}$ & $\begin{array}{l}\text { Initially left hand; } \\
\text { subsequently lower } \\
\text { limbs and right hand }\end{array}$ & 6 & yes & no & $\begin{array}{c}\text { ele- } \\
\text { vated }\end{array}$ & $\begin{array}{l}\text { Left tib-ant } \\
\text { and } L \text {. triceps } \\
\text { positive }\end{array}$ & improved \\
\hline Bates et al & 62 & $\mathrm{~F}$ & $\begin{array}{l}\text { Hand muscles; proximal } \\
\text { lower limb muscles; } \\
\text { facial muscles }\end{array}$ & 2 & yes & no & $\begin{array}{c}\text { ele- } \\
\text { vated }\end{array}$ & $\begin{array}{l}\text { R. deltoid } \\
\text { x twice } \\
\text { positive }\end{array}$ & improved \\
\hline Stark 1978 & 45 & $\mathrm{~F}$ & $\begin{array}{l}\text { Left hand and arm - } \\
\text { subsequently proximal } \\
\text { leg muscles left } \\
\text { worse than right }\end{array}$ & 6 & no & no & $\begin{array}{c}\text { ele- } \\
\text { vated }\end{array}$ & positive & $\begin{array}{c}\text { arrest of the } \\
\text { process }\end{array}$ \\
\hline Van Kasteren 1979 & 55 & $\mathrm{~F}$ & $\begin{array}{l}\text { Asymmetrical distal } \\
\text { leg weakness; left } \\
\text { forearm and hand. } \\
\text { Subsequently } R \text {. } \\
\text { forearm and hand }\end{array}$ & 6 & no & $\begin{array}{l}\text { yes at } \\
\text { onset }\end{array}$ & $\begin{array}{c}\text { ele- } \\
\text { vated }\end{array}$ & positive & improved \\
\hline Our patient & 52 & $\mathrm{~F}$ & $\begin{array}{c}\text { Left calf muscles; } \\
\text { subsequently proximal } \\
\text { leg muscles }\end{array}$ & 7 & no & no & $\begin{array}{c}\text { ele- } \\
\text { vated }\end{array}$ & positive & $\begin{array}{l}\text { arrest of } \\
\text { the process }\end{array}$ \\
\hline
\end{tabular}

EATON, L.M. (1954). The Perspective of Neurology in Regard to Polymyositis. A Study of 41 Cases. Neurology. 4: 245-263.

HOLLINRAKE, K. (1969). Polymyosit is Presenting As Distal Muscle Weakness. A Case Report. Journal of Neurological Sciences. 8 : 479-484.

PEARSON, C.M. (1966). Polymyositis. Annual Review of Medicine. 17: 63-82.

ROSE, A., WALTON, J.N. (1966). Polymyosit is:
A Survey of 89 Cases With Particular Reference to Treatment and Prognosis. Brain. 89: 747-768.

ROWLAND, L.P..Advances In Neurology. Vol. 17, page 69. Raven Press, New York. (1977).

STARK, R.J. (1978). Polymyositis Presenting With Severe Weakness Involving Only One Arm. Australia and New Zealand Journal of Medicine. 8: 544-546.
VAN KASTEREN, B.J. (1979). Polymyositis Presenting With Chronic Progressive Distal Muscular Weakness. Journal of Neurological Sciences, 41: 307-310.

WALTON, J.N. (1974). Disorders of Voluntary Muscle. Ed. 3 page 614. Churchill Livingstone. Edinburgh. 